Volume. 5 Number. 1

Period: January - June 2021; page 31-39

p-ISSN : 2580-1112; e-ISSN : 2655-6669

Jurnal Ilmiah Keperawatan Orthopedi

(JIKO)

Copyrighr@2020

Article history:

The author owns the copyright of this article

Received: February 28, 2021

journal homepage: https://ejournal.akperfatmawati.ac.id

Revised: March 02, 2021

DOI : $10.46749 /$ jiko.v5i1.59

\title{
Description of Knowledge and Attitudes of Teenagers to Sexually Transmitted Diseases in Public Senior High School 8 Banjarmasin
}

\author{
${ }^{1}$ Nur Cahyani Ari Lestari, ${ }^{2}$ Syahrida Wahyu Utami, ${ }^{3}$ Sri Purwanti \\ 1,2,3 Abdi Persada Academy of Midwifery, Banjarmasin - Indonesia \\ e-mail: nurcahyaniarilestari@gmail.com, rhiedha.utami@gmail.com, wanty2727@gmail.com
}

\begin{abstract}
Sexually transmitted diseases are diseases that are transmitted through sexual intercourse with multiple partners and are a form of behavior that deviates and exceeds boundaries or is also called juvenile delinquency. Basically juvenile delinquency refers to a form of adolescent behavior that is not in accordance with the norms that exist in society. At Public Senior High School 8 in the Alalak Tengah Community Health Center, Banjarmasin City, there is one person who quit school because he wants to get married. This study aims to describe the knowledge and attitudes of adolescents against sexually transmitted diseases in Public Senior High School 8 Banjarmasin. This research was conducted at Public Senior High School 8 Banjarmasin with a descriptive research method. Population of 153 people with a sample of 62 people, the sampling technique with proposive sampling where sampling is based on a certain consideration made by the researcher. The results of the research at Public Senior High School 8 Banjarmasin were respondents who had good knowledge of 15 people $(24.19 \%)$, quite 38 people $(61.29 \%)$, less than 7 people (11.29\%), and 2 people who were not good 23). respondents who had a supportive or positive attitude towards sexually transmitted diseases were 29 people (46.77\%) and negative attitudes towards sexually transmitted diseases were 33 people (53.23\%). Based on the research, it was concluded that the knowledge of Public Senior High School 8 Banjarmasin students about sexually transmitted diseases was in the moderate category and had a negative attitude.
\end{abstract}

Keywords: Knowledge, Attitudes, Sexually Transmitted Diseases

\section{Introduction}

Sexually transmitted diseases (STDs) are diseases transmitted through sexual contact, there are approximately 30 types of microbes (bacteria, viruses and parasites) that can be transmitted through sexual contact. The most common conditions are gonorrhea, chlamydia, syphilis, trichomoniasis, chancroid, genital herpes, Human Immunodeficiency Virus (HIV) infection and hepatitis B.
Some of them, HIV and syphilis, can also be transmitted from mother to child during pregnancy and birth, and through blood and body tissues. Until now, sexually transmitted diseases are still a health, social and economic problem in many countries.

The results of a study based on the WHO (World Health Organization) estimate that an average of $100 \%$ of all adolescents in the world, an estimated $47 \%$ have engaged in casual sexual 
behavior. This figure is also closely related to the high number of people with HIV/AIDS (Human Irnmunodeviciency Virus/Aquared Immuno Deficiency Virus) which continues to increase every year. It is proven that in 2002 the number of sufferers was estimated at 90,000 to 160,000 cases. This figure is increasing

The latest incidence of sexually transmitted diseases including HIV AIDS in Indonesia was reported up to June 2012, according to data from the Directorate General of PP \& PL dated August 15, 2012, HIV cases From April to June 2012 the number of new HIV cases reported was 3,892 cases. from April to June 2012 the number of new AIDS cases reported was 1,673 cases.

According to data from the South Kalimantan provincial government, the number of people with HIV / AIDS in South Kalimantan continues to increase. Currently there are 440 cases recorded, and seven of them happened to babies who contracted from a mother with the disease.

Data obtained from the health office of the city of Banjarmasin shows that in 2009 there were 49 STD cases, while in 2010 there were 40 STD cases, and in 2011 there were 33 STD cases, however in June 2012 it had increased to 107 cases. With 107 HIV cases in Banjarmasin, transmission of the disease is in the top rank compared to 13 other districts and cities in South Kalimantan Province. In addition, HIV / AIDS cases also experienced an increase from 52 cases in 2011 to 57 cases in June 2012. It is the second HIV / AIDS case after Tanah Bumbu District.

Knowledge about sexually transmitted infections can be increased by providing reproductive health education starting in adolescence. Reproductive health education among adolescents not only provides knowledge about reproductive organs, but also about the dangers caused by promiscuity, such as sexually transmitted diseases and unexpected pregnancies or high-risk pregnancies.

The preliminary study was carried out by the author on March 25, 2013 through interviews with the counseling teacher (BP teacher) at SMAN 8 Banjarmasin, it is known that there is no written data or diagnosed results from the doctor's examination regarding students with sexually transmitted diseases.

Researchers get information from the teacher BK (Student Section) and the deputy principal, that students of SMAN 8 Banjarmasin rarely get information or counseling from medical personnel or from the puskesmas regarding sexually transmitted infections in adolescents. Apart from that, the authors also get information that students at SMAN 8 Banjarmasin are prone to promiscuity which is the main cause of infection with sexually transmitted diseases.

In addition, interviews were also conducted with 10 students (5 from grade 1 and 5 from grade 2) as many as 3 people $(30 \%)$ said that a sexually transmitted infection is a disease related to reproductive organs while 7 people $(70 \%)$ did not know about sexually transmitted infections.

Based on the information from the Extension Guidance teacher at SMAN 8 Banjarmasin, there was no curriculum that discussed sexually transmitted infections and there was never a forum for youth consultation related to sexually transmitted infections by health workers. regarding the problem of sexually transmitted infections that have an impact on deviant sexual behavior, such as having sex outside of marriage, having sexual intercourse without using a condom and changing partners.

The general objective of this study was to describe the knowledge and attitudes of adolescents against sexually transmitted diseases at Public Senior High School 8 Banjarmasin.

The specific objective of this study was to identify knowledge, attitudes, and 
a combination of adolescent knowledge and attitudes towards sexually transmitted diseases.

\section{Method}

The research conducted is descriptive. This research method was used to determine the description of knowledge and attitudes of adolescents against sexually transmitted diseases at Public Senior High School 8 Banjarmasin.

\section{Result}

\section{Research Location Overview}

Public Senior High School 8 Banjarmasin building was founded in 1991 on a land area of $8,109 \mathrm{~m} 2$ and a building area of $1920.5 \mathrm{~m} 2$ located on Jl. Public Senior High School 8 RT. 23 RW. 02 NO. 26 Kec. North Banjarmasin, Banjarmasin City, South Kalimantan Province and with the following boundaries:

1. The north is bordered by residential residents

2. To the west is bordered by residential residents

3. In the east, it is bordered by rice fields owned by the residents

4. In the south, it is bordered by SMPN 13 Banjarmasin

Programs implemented by Public Senior High School 8 Banjarmasin include formal learning activities, remedial learning, enrichment learning, physics practicum, chemistry lab, biology lab, language practicum and computer practicum.

According to the data obtained by Public Senior High School 8 Banjarmasin, it is an outstanding school at both the city and provincial levels. In addition to the academic achievements of Public Senior High School 8 Banjarmasin, there are also many nonacademic championship achievements. In this school, students receive guidance and supervision from the school, namely during class hours, while after

\section{Number of Students}

Based on data from the Public Senior High School 8 Banjarmasin in 2013, the total number of students from class $\mathrm{X}$ to class XII was 523 people consisting of 225 male students and 298 female students as shown in table 1:

Table 1. Based on the Number of Students in

Public Senior High School 8 Banjarmasin in 2012/2013

\begin{tabular}{llcc}
\hline \multirow{2}{*}{ No } & \multirow{2}{*}{ Class } & \multicolumn{2}{c}{ Total students } \\
\cline { 3 - 4 } & & Man & Woman \\
\hline 1. & Class X & 82 & 121 \\
2. & Class XI & 63 & 90 \\
3. & Class XII & 80 & 87 \\
\hline \multicolumn{2}{l}{ Amount } & 225 & 298 \\
\hline
\end{tabular}

Source: Public Senior High School 8 Banjarmasin

Public Senior High School 8 Banjarmasin has 3 class criteria, namely class X (6 classes), class XI (5 classes), and class XII (5 classes) with an average number of students per class between 2930 people.

\section{Number of Teachers}

Table 2. Distribution based on the number of teachers in Public Senior High School 8 Banjarmasin in 2012/2013

\begin{tabular}{clc}
\hline No & Type of Power & $\begin{array}{c}\text { Number of } \\
\text { Teachers or } \\
\text { Employees }\end{array}$ \\
\hline 1 & Headmaster & 1 \\
2 & Vice Principal & 4 \\
3 & Religion teacher & 2 \\
4 & Computer teacher & 2 \\
5 & Arabic Teacher & 1 \\
6 & English teacher & 5 \\
7 & Indonesian Language Teacher & 3 \\
8 & Math teacher & 5 \\
9 & Science teache & 7 \\
10 & Social studies teacher & 10 \\
11 & Physical Education teacher & 2 \\
12 & Local content teacher & 1 \\
13 & Cultural Arts Teacher & 1 \\
14 & Citizenship Teacher & 3 \\
15 & Counseling Guidance Teacher & 3 \\
16 & Head of administration & 1 \\
17 & Administration Staff & 5 \\
\hline
\end{tabular}

Source: School Profile Data

\section{Means of Consultation}

The consultation facility available at Public Senior High School 8 Banjarmasin is an Amount 1 room with an area of $4 \times 5$ $\mathrm{m} 2$ which is managed by 3 counseling 
guidance teachers (BP). The room is used to provide counseling guidance.

\section{Special Data on Research Results}

1. Youth Knowledge

Table 3 Frequency Distribution Based on Adolescent Knowledge of Sexually Transmitted

Diseases in Public Senior High School 8 Banjarmasin in 2013

\begin{tabular}{clcc}
\hline No & Knowledge & Frequency & Percentage \\
\hline 1. & Good & 15 & 24,19 \\
2. & Enough & 38 & 61,29 \\
3. & Less & 7 & 11,29 \\
4. & Not good & 2 & 3,23 \\
\hline & Amount & 62 & 100 \\
\hline
\end{tabular}

Source: Primary Data

Table 3 provides an illustration that out of 62 adolescents, most of them at Public Senior High School 8 Banjarmasin have sufficient knowledge about sexually transmitted diseases, namely 38 people $(61.29 \%)$.

\section{Youth Attitude}

Table 4.Frequency Distribution Based on Adolescent Attitudes Toward Sexually Transmitted Diseases in Public Senior High School 8 Banjarmasin in 2013

\begin{tabular}{cccc}
\hline No & Attitude & Frequency & Percentage \\
\hline 1. & Positive & 29 & 46,77 \\
2. & Negative & 33 & 53,23 \\
\hline \multicolumn{2}{r}{ Amount } & 62 & 100
\end{tabular}

Source: Primary Data

Table 4 illustrates that out of 62 adolescents, most of the adolescents at Public Senior High School 8 Banjarmasin have negative attitudes towards sexually transmitted diseases, namely 33 people $(53.23 \%)$.

\section{Cross tabulation of knowledge and attitudes}

Table 5.Frequency Distribution Based on Tabulation of Knowledge and Attitudes of Adolescents Against Sexually Transmitted Diseases in Public Senior High School 8 Banjarmasin in 2013

\begin{tabular}{|c|c|c|c|c|c|c|c|}
\hline \multirow{3}{*}{ No } & \multirow{3}{*}{ Knowledge } & \multicolumn{4}{|c|}{ Attitude } & \multirow{3}{*}{$\mathrm{n}$} & \multirow{3}{*}{$\%$} \\
\hline & & \multicolumn{2}{|c|}{ Positive } & \multicolumn{2}{|c|}{ Negative } & & \\
\hline & & $\mathrm{N}$ & $\%$ & $\mathrm{~N}$ & $\%$ & & \\
\hline 1 & Good & 7 & 46,67 & 8 & 53,33 & 15 & 100 \\
\hline 2 & Enough & 18 & 44,44 & 20 & 55,56 & 38 & 100 \\
\hline 3 & Less & 2 & 28,57 & 5 & 71,43 & 7 & 100 \\
\hline \multirow[t]{2}{*}{4} & Not good & 0 & 0 & 2 & 100 & 2 & 100 \\
\hline & Amount & 29 & & 33 & & 62 & \\
\hline
\end{tabular}

Source: Primary Data

Table 5 illustrates that out of 15 well-informed adolescents, there were 8
(53.33\%) who had negative attitudes, while of the 38 adolescents with sufficient knowledge, there were 20 people $(55.56 \%)$ who had negative attitudes, while of the 7 knowledgeable respondents. less there are 5 people $(71.43 \%)$ who are negative. Meanwhile, from 2 people who had bad knowledge, there were 2 people (100\%) who were negative.

\section{Discussion}

Sexually Transmitted Diseases (STDs) is a reproductive tract infection whose main mode of transmission is through sexual contact but can also be transmitted through blood transfusions or direct contact with blood fluids, and from mother to child during pregnancy, childbirth or after birth. Sexually Transmitted (STD) can be caused by bacteria, fungi, viruses, and parasites.

\section{Knowledge}

Knowledge is the result of knowing and occurs after people sense a certain object and most of human knowledge is obtained through the eyes and ears. Broadly speaking, knowledge is divided into 6 levels, namely knowing, understanding, applying, analyzing, synthesizing, and then evaluating (Notoatmodjo, 2007).

A person's knowledge is influenced by internal and external factors. Internal factors include: a) physical, mental and social health, b) intelligence level, c) attention (if someone's attention to a material is low / lacking, then the understanding of the material will decrease / decrease), d) interest (activity of interest a person, is constantly paid attention to with a sense of pleasure, e) talent / ability acquired through the learning / training process. External factors that affect a person's knowledge are: a) family (as the first and foremost educational institution), b) learning methods, c) society where the individual is located.

Based on table 2, it shows that the 
knowledge of adolescents in Public Senior High School 8 Banjarmasin is from 62 well-informed adolescents, 15 people $(24.19 \%), 38$ people $(61.29 \%)$ knowledgeable, 7 people with less knowledge. (11.29\%), and 2 people with bad knowledge (3.23\%)

Bad knowledge obtained from the results of questionnaires filled out by adolescents at Public Senior High School 8 Banjarmasin because adolescents do not understand the questions asked by researchers and their lack of knowledge about sexually transmitted diseases is shown from the results of questionnaires distributed to respondents, namely 40 people ( $64.52 \%$ ) who do not know about the body systems that are attacked by the HIV / AIDS virus.

The lack of knowledge shown by adolescents at Public Senior High School 8 Banjarmasin is influenced by the lack of information obtained by adolescents about sexually transmitted diseases, this is supported by a questionnaire distributed to respondents, namely 26 people $(41.94 \%)$ who do not know about the causes of HIV disease. / AIDS.

The sufficient knowledge shown by adolescents at Public Senior High School 8 Banjarmasin was supported by the results of distributing questionnaires that as many as 62 teenagers, 52 people $(83.87 \%)$ who answered correctly about the meaning of sexually transmitted diseases, and as many as 50 people $(80.65 \%)$ ) respondents who know or answer questions about the mode of transmission of sexually transmitted diseases.

While the good knowledge shown by adolescents in Public Senior High School 8 Banjarmasin, this means that wellinformed adolescents understand and care about their own health, this is supported by the results of the questionnaire answers obtained by 54 people $(87.10 \%)$ who answered correctly about how long it took until the onset of Symptoms of HIV I AIDS have only been recognized in patients infected with HIV / AIDS.

Based on the data obtained, it was stated that $3.23 \%$ of students had poor knowledge and $11.29 \%$ of students had less knowledge. It turns out that there are still students who do not know about sexually transmitted diseases even though there are many sources related to references to a theory related to sexually transmitted diseases.

But basically humans as independent individuals who are socially integrated have the source of all knowledge, namely family, especially parents. The community system of a family in Indonesia, especially Banjarmasin, South Kalimantan, emphasizes the pattern of educating a tradition from generation to generation.

This is quite contrary to other social patterns of society which tend to be open to new ideas and information. No exception regarding traditions related to taboos, especially about sexuality.

The pattern of students who have long been imprinted in the family environment. This taboo tradition makes not all parents able to provide sex education, especially about sexuality for their children. Taboo has created a lot of distance between mother, father and child due to the lack of interpersonal closeness (mother, father, child) in the family.

The pattern of students that has developed so far is only parents giving restrictions to children without providing an understanding of the essence and impact of a behavior related to sexuality. The mindset developed by the majority of parents assumes that their child gets all the knowledge from school. Meanwhile, not all schools are taught a special lesson on, "Sex Education".

At Public Senior High School 8 Banjarmasin itself, students do not get sexuality lessons as one of the learning curricula. They only get education about ethics and religious education which they only get once a week. This lesson is not sufficient to provide a real example of 
sex education because this lesson teaches about the norms, prohibitions and responsibilities of an act.

Service places such as the Puskesmas (PKPR) as a health facility that is tasked with providing counseling, especially to adolescents in the Poskesmas area of Alalak Tengah, are less active in providing counseling about teenage sexuality.

Of course this is not enough to provide information to adolescents to fulfill their biological desires, their very high curiosity for sexuality. So that adolescents look for other sources of knowledge related to sexuality from friends, mass media, and electronics such as books, magazines, films, the internet.

\section{Attitude}

Attitude is a readiness or willingness to act, and not an implementation of a particular motive. In other words, the attitude function is not yet an action (open reaction) or activity, but rather a predisposition to behavior (action) or closed reactions. Attitude consists of 3 main components, namely trust, emotional life, and tendency to act.

These three components together form a complete attitude (total attidude). The factors that influence the formation of attitudes are: a) personal experience, b) the influence of other people who are considered important, c) mass media, d) educational institutions and religious institutions, e) the influence of emotional factors (Notoatmodjo, 2007).

Attitude is a form of statement based on emotion which functions as a kind of channeling of frustration or a diversion from the defense mechanism of the ego. Based on table 4.3 of the results of research at Public Senior High School 8 Banjarmasin, from 62 respondents, it was found that 29 respondents had a positive attitude $46.77 \%$ ) and negative attitudes towards sexually transmitted diseases, namely 33 people (53.23\%) (Azwar, 2005).

Based on the data obtained, the attitudes of adolescents towards sexually transmitted diseases at Public Senior High School 8 Banjarmasin have negative attitudes, due to a lack of knowledge and attitudes of wanting to care about their own health, this is supported by the questionnaire statement no 4, namely "Teens may have intercourse. sex before marriage "found as many as 35 people $(56.45 \%)$ adolescents who strongly agree about this statement, meaning that they do not understand more about the impact of premature sexual behavior.

The positive attitude shown by Public Senior High School 8 Banjarmasin adolescents, was caused by sufficient knowledge and a feeling of caring about healthy associations, this was supported by the questionnaire question No. 8, namely "The impact of sexual intercourse with multiple partners will lead to contracting STDs." 26 people (41.94\%) strongly agreed with the statement, and as many as 3 people $(4.84 \%)$ who disagreed with the statement "Sexual education needs to be given early on".

During adolescence, biological, psychological and social development occurs. During this period, sexual volatility has increased and often leads to deviant behavior that can interfere with health, such as premarital sex, unwanted pregnancy, abortion, and sexually transmitted diseases.

Based on the number of respondents who have a negative attitude towards sexually transmitted diseases, it is found that even though many respondents are knowledgeable enough, they do not necessarily have a positive attitude towards sexually transmitted diseases.

The occurrence of negative attitudes in the form of behavioral deviations in adolescents can be influenced by other factors, including promiscuity, environmental influence, unemployment and lack of education, socio-economic, and local culture (customs).

Cross tabulation of knowledge and 


\section{attitudes}

Based on table 4 of the results of research at Public Senior High School 8 Banjarmasin, it was found that out of 15 respondents who had good knowledge there were 7 people $(46.67 \%)$ who had a positive attitude and 8 people $(53.33 \%)$ who had negative attitudes, while from 36 respondents 18 people with sufficient knowledge (44.44\%) were positive and 20 people $(55.56 \%)$ had negative attitudes, then from 7 respondents who were less knowledgeable there were 2 people $(28.57 \%)$ who were positive and 5 people $(71.43 \%)$ who have a negative attitude. and of the 2 respondents who had poor knowledge, 2 (100\%) had a negative attitude towards sexually transmitted diseases.

Knowledge is the result of knowing and occurs after people sense a certain object and most of human knowledge is obtained through the eyes and ears. Broadly speaking, knowledge is divided into 6 levels, namely knowing, understanding, applying, analyzing, synthesizing, and then evaluating (Notoatmodjo, 2007).

Attitude consists of 3 main components, namely trust, emotional life, and the tendency to act. These three components together form a complete attitude (total attitude). In determining this complete attitude, knowledge, thoughts, beliefs, and emotions play an important role (Notoatmodjo, 2007).

In their social interactions, individuals form certain patterns of attitudes towards the various psychological objects they face. Among the various factors that influence the formation of attitudes are personal experiences, culture, other people who are considered important, mass media, educational and religious institutions or institutions, as well as emotional factors in individuals (Azwar, 2010).

Based on the results of the above research that not all adolescents who have good knowledge will form a positive attitude or vice versa, adolescents who have less knowledge will have a negative attitude towards sexually transmitted diseases.

As from the research results above adolescents who have good knowledge but have a negative attitude, this can be caused by global information or exposure to easily accessible media that can influence adolescents to adapt to unhealthy habits such as; smoking, drug abuse, alcoholic drinks, porn videos that accelerate sexual age and lead to high risk behaviors / behaviors.

Good knowledge and positive attitude shown by respondents at Public Senior High School 8 Banjarmasin, this means that these adolescents understand and understand about sexually transmitted diseases and tend to be positive.

Sufficient knowledge but a negative attitude shown by respondents, possibly influenced by a high sense of curiosity in adolescents who are not accompanied by considerations that result in further actions, for example: having early sexual intercourse with a partner (lover) and so on.

Moreover, most of them have an attitude of not wanting to be responsible for their sexual behavior. Knowledge is sufficient but the positive attitude shown by respondents is likely to be influenced by sufficient knowledge and have behaviors that can refrain from falling into promiscuity.

Adolescents who are less knowledgeable but have a positive attitude shown by adolescents at Public Senior High School 8 Banjarmasin, this is probably influenced by a lack of information about sexually transmitted diseases so that there is a lack of encouragement from themselves to get education about sexually transmitted diseases but are not easily influenced by bad behavior. around their environment.

Adolescents who are less knowledgeable and have negative 
attitudes may be influenced by ignorance or ignorance of the development of knowledge about sexually transmitted diseases so that there is less encouragement for adolescents to get education about sexually transmitted diseases. In fact, the lack of knowledge and negative attitudes of adolescents can cause problems for adolescents such as trying to have sex at an early age, changing sexual partners, and so on.

Attitude formation is a complex process within the individual. From the research results that not all adolescents who have good knowledge will form a positive attitude or vice versa for adolescents who have less knowledge and have a negative attitude towards sexually transmitted diseases.

The formation of a positive or negative attitude is not only influenced by knowledge but also depends on various other factors. To be able to form the basis for the formation of attitudes there must be a balance between knowledge, emotional and psychological in adolescents and support from the surrounding environment, namely parents, teachers and health workers to provide special guidance and attention in delivering sex education programs to adolescents, especially regarding the impact of sexual patterns. deviating from it can lead to sexually transmitted diseases.

Based on this research, it was found that the majority of students from Public Senior High School 8 Banjarmasin had sufficient knowledge and had a negative attitude towards sexually transmitted diseases.

This is sufficient to prove that even though someone has sufficient knowledge, they are not necessarily able to apply it to their attitude in dealing with these problems. In general, adolescents do not have filters to filter all the information they get, so teenagers need accurate information from the authorities. Not only from schools that are a place to gain knowledge, but they need information and advice from parents, religious leaders, and health workers, especially in the field of PKPR Puskesmas. So that in this case it is not only teenagers who are responsible for all the "naughtiness" but all the parties around them.

\section{Conclusion}

The knowledge of adolescents about sexually transmitted diseases at Public Senior High School 8 Banjarmasin who have good knowledge is 15 people $(24.19 \%)$, quite a number of 38 people (61.29\%), less than 7 people $(11.29 \%)$, while those who are knowledgeable not good 2 people (3.23\%).

Adolescent attitudes towards sexually transmitted diseases at Public Senior High School 8 Banjarmasin who have a positive attitude are 29 people $(46.77 \%)$ and negative attitudes, namely 33 people $(53.23 \%)$.

The knowledge and attitudes of adolescents about sexually transmitted diseases at Public Senior High School 8 Banjarmasin illustrate that out of 15 wellinformed respondents there were 7 people (46.67\%) who were positive and there were 8 people $(53.33 \%)$ who were negative, while out of 38 adolescents with sufficient knowledge, there were 18 people $(47.37 \%)$ who had a positive attitude and 20 people (52.63) who had negative attitudes, while of the 7 respondents who had insufficient knowledge, there were 2 people $(28.57 \%)$ who had a negative attitude. positive and 5 people $(71.43 \%)$ who were negative, while from 2 people with bad knowledge there were 2 people $(100 \%)$ who were negative.

\section{Bibliography}

Admin, 2008. Kesehatan Reproduksi. http://www.kespro.info. Diperoleh tanggal 20 Januari 2011

Anton, 2007. Wanita Indonesia. http://www.hanyawanita.com. 
diperoleh tanggal 20 Januari 2011

Arikunto, S. 2006. Prosedur Penelitian Suatu Pendekatan Praktek. Jakarta: PT. Rineka Cipta. Hal. 149.

Azwar, S. 2007. Reliabilitas dan Validitas. Jogjakarta: Pustaka Pelajar. Hal. 19.

Budiarto, E. 2003. Biostatistika uniuk Kedokteran dan Kesehatan Masyarakat. Jakarta: EGC.

Dayakisni, T. 2001. Psikologi Sosial. Malang: Universitas Muhammadiyah Malang. Hal. 5158.

Drhandri, 2008. Remaja Indonesia. http://drhandri.wordpress.com. Diperoleh tanggal 20 Januari 2011

Farid, 2005. Karakterislik Remaja di Masa Reproduksi. http://suaramerdeka.com. Diperoleh tanggal 20 Januari 2011

Fitria, A, 2009. Hubungan Tingkat Pengetahuan Kesehatan reproduksi dengan Sikap Remaja Terhadap seks diluar nikah Class XI SMA N 1 Karanggede Boyolali.

Skripsi (Tidak Diterbitkan). STIKES Semarang.

Hidayat, A.A. 2007. Metode Penelitian Kebidanan: Teknik Analisa Data. Jakarta: Salemba Medika. Hal. 8795.

Moersintowarti, B.N. 2002. Buku Ajar Tumbuh Kembang Anak dan Remaja. Jakarta: Sagung Seto. Hal. 138.

Nitya, 2009. Sejak Penyebab Seks Pranikah.

http://www/nityabersama.co.ccDipe rolehtanggal 20 Januari 2011

Notoatmodjo, S. 2003. Ilmu Kesehatan Masyarakat: Prinsip-Prinsip Dasar. Jakarta: PT. Rineka Cipta. Hal. 116, 131.

Nursalam, 2003. Konsep dan Penerapan Metodologi Penelitian Ilmu Keperawatan. Jakarta: Salemba Medika. Hal. 91.
Rixco, 2008. Kesehatan Reproduksi Remaja. http://rixco.multiply.com. Diperoleh tanggal 22 Januari 2011

Sarwono, S.W. 2007. Psikologi Remaja. Jakarta: Raja Grafindo Persada. Hal. 24-25, 52-58, 142-165.

Arikunto, Suharsimi. (2002). Prosedur Penelitian Suatu Pendekatan Praktek. Cetakan ke 12. Edisi Revisi V. Jakarta, Rineka Cipta.

Azwar, Saifuddin. (1998). Perilaku Manusia Untuk Keperawatn. Jakarta, EGC.

Depkes RI. (1998). Pedoman Pemantauan Wilayah Setempat Kesehatan Ibu Dan Anak. Jakarta, Direktorat Bina kesehatan Kesehatan.

Huliana, Mellyana. (2003). Perawatan Ibu Pasca Melahirkan. Jakarta , Puspa Swara.

Ladewig, Patricia. (2006). Asuhan Keperawatan Ibu Dan Bayi Baru Lahir. Jakarta , EGC.

Lee, Kerrie. (2006). Segala Suatu Tentang Payudara. Jakarta, Arcan.

Purwanto, Heri. (1999). Pengantar Perilaku Manusia Untuk Keperawatan. Jakarta, EGC.

Notoadmodjo, S. (2003). Metodologi penelitian Kesehatan. Jakarta, Rineka Cipta.

Notoadmojo, S. (2003). Pendidikan Dan Perilaku Kesehatan. Jakarta, Rineka Cipta.

Nursalam. (2001). Pendekatan Praktis Metodologi Penelitian. Jakarta, CV Sagung Seto.

Soetiningsih . (1997). ASI Petunjuk Untuk Tenaga Keshatan. Jakarta, EGC.

Verralls, Sylvia. (2003). Anatomi Dan Fisiologi Terapan Dalam Kebidanan Edisi 3. Jakarta, EGC.

Widayatun, Tri Rusmi.. (1999). Ilmu Perilaku. Jakarta, CV Sagung Seto.

WWW. By Pusat Data Dan Informasi @ Departemen kesehatan 2005. Co 